\title{
The Hairless Gene: A Putative Navigator of Hair Follicle Development
}

\author{
Jeong-Ki $\mathrm{Kim}^{1,2}$, Bong-Kyu $\mathrm{Kim}^{1,2}$, Jong Keun \\ Park $^{1,2}$, Jee-Hyun $\mathrm{Choi}^{1,2}$ and Sungjoo Kim \\ Yoon $^{1,2 *}$
}

Departments of ${ }^{1}$ Medical Lifescience and ${ }^{2}$ Biomedical Sciences, The Catholic University of Korea, Seoul 137-701, Korea

\begin{abstract}
The Hairless (HR) gene regulates the expression of several target genes as a transcriptional corepressor of nuclear receptors. The hair follicle (HF), a small independent organ of the skin, resides in the epidermis and undergoes regenerative cycling for normal hair formation. HF development requires many genes and signaling pathways to function properly in time and space, one of them being the $H R$ gene. Various mutations of the $H R$ gene have been reported to cause the hair loss phenotype in rodents and humans. In recent studies, it has been suggested that the $H R$ gene is a critical player in the regulation of the hair cycle and, thus, HF development. Furthermore, the $H R$ gene is associated with the Wnt signaling pathway, which regulates proliferation and differentiation of cells and plays an essential role in hair and skin development. In this review, we summarize the mutations responsible for human hair disorders and discuss the roles of the $H R$ gene in $\mathrm{HF}$ development.
\end{abstract}

Keywords: hairless, corepressor, hair follicle, hair cycle, hair loss

\section{Introduction}

The hair follicle (HF) is a small independent organ of the skin that undergoes regenerative cycling for normal hair formation. HF formation during embryogenesis and regenerative cycling periods occurs through close crosstalk between epithelial and mesenchymal cells (Millar, 2002). HF cycling is composed of the growth phase (anagen), regressing phase (catagen), and resting phase (telogen) (Paus et al., 2004).

The HF, a complex skin appendage, is composed of many different compartments, including the sebaceous

*Corresponding author: E-mail sjkyoon@catholic.ac.kr Tel +82-2-2258-7474, Fax +82-2-594-2385

Accepted 1 September 2011 gland, which produces oil; the bulge, which is the niche for stem cells; the bulb, which has actively proliferating and differentiating cells; and the stalk, which is divided into three layers the hair shaft, inner root sheath (IRS), and outer root sheath (ORS) (Fig. 1; Blanpain et al., 2006). Each layer expresses layer-specific keratin proteins that contribute to HF keratinization, leading to formation of a rigid structure (Langbein et al., 2005; Shimomura et al., 2010).

The hairless $(H i)$ gene was first cloned in the 'hairless' $\left(H^{h}\right)$ mouse, whose genome contained an endogenous murine leukemia provirus in intron 6 of this gene (Stoye et al., 1988). Homozygous $H r^{\text {hr }}$ mice initially grow hair until the beginning of the hair cycle, when they start to lose hair from the head and continue to lose it until reaching the caudal area (Brooke, 1926). Then, this hairless phenotype is permanent hence the name 'hairless'. A study of $H r^{h r}$ mutant mice has revealed that the $\mathrm{Hr}$ gene is important for hair growth and the hair cycle (Panteleyev et al., 1998). The rat $h r$ gene was isolated as a gene that is regulated by thyroid hormone (Thompson, 1996), and the human $H R$ gene was identified as a gene that is responsible for congenital hair disorders (Ahmad et al., 1998a; Ahmad et al., 1998b; Cichon et al., 1998).

The mouse, rat, and human $\mathrm{Hr}$ genes encode an approximately $130-\mathrm{kDa}$ protein $(\mathrm{HR})$ that localizes to the nucleus and contains a single zinc-finger domain (Cachon-Gonzalez et al., 1994; Djabali et al., 2001). The

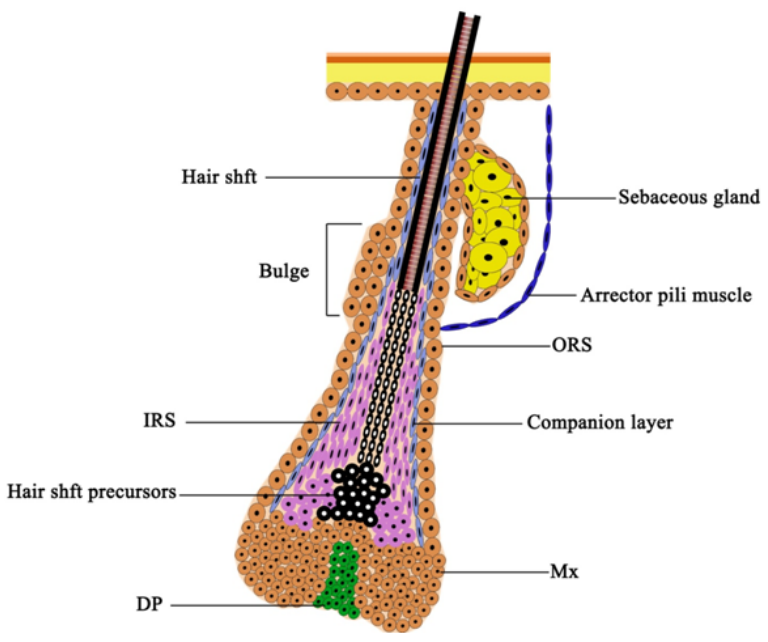

Fig. 1. Schematic of hair follicle (Blanpain et al., 2006). 
mouse $H r$ gene is expressed mainly in the brain and skin, with minor expression elsewhere (Cachon-Gonzalez et al., 1994; Cachon-Gonzalez et al., 1999).

In this review, we will summarize the molecular characteristics of the $\mathrm{Hr}$ gene, the roles of the $\mathrm{Hr}$ gene in $\mathrm{HF}$ development, and the mutations that are responsible for human hair disorders.

\section{$H R$, a Corepressor of Nuclear Recep- tors}

The HR acts as a transcriptional corepressor through interaction with nuclear receptors. Nuclear receptors regulate the expression of specific genes as transcription factors in developmental processes and other various physiological processes. Typically, nuclear receptors activate the transcription of target genes through binding to their ligands, such as steroid hormone, thyroid hormone, and other small molecules, including retinoic acids and vitamin $D$. In some cases, nuclear receptors repress transcription in the absence of their ligands (Jepsen et al., 2002; Mangelsdorf et al., 1995; Privalsky, 2004; Smith et al., 2004), and this repression occurs through association with its corepressors, such as nuclear receptor corepressor (N-CoR), silencing mediator for retinoic acid and thyroid hormone receptors (SMRT), and HR (Chen et al., 1995; Horlein et al., 1995; Sande., 1996; Thompson et al., 2006; Zhongjian et al., 2006). $\mathrm{HR}$ has been shown to interact with thyroid hormone receptor (TR), retinoic acid orphan receptor $\alpha(\mathrm{ROR} \alpha)$, and vitamin D receptor (VDR) (Thompson, 1996; Hsieh et al., 2003; Moraitis et al., 2002).

\section{Interaction with the thyroid hormone receptor and retinoic acid orphan receptor- $\alpha$}

TR is a receptor for thyroid hormone, which is an essential component of development of the central nervous system (CNS), and functions as a transcription factor that regulates the expression of target genes in response to thyroid hormone binding. The interaction between HR and TR was found in a yeast two-hybrid screen for HR-interacting proteins, and its interaction was reduced in the presence of thyroid hormone (Thompson et al., 1997). In vitro biochemical assays and in vivo coimmunoprecipitation experiments have demonstrated that $h r$ has two independent TR-interacting domains (TR-ID)-TR-ID1 and TR-ID2 span amino acids 816-830 and 1026-1038 of the rat $h r$ gene, respectively (Fig. 2). These TR-ID domains of HR contain a consensus sequence, a stretch of hydrophobic residues: I/LIXXL/NV. This essential motif is similar to those of other corepressors, such as N-CoR and SMRT (Potter et

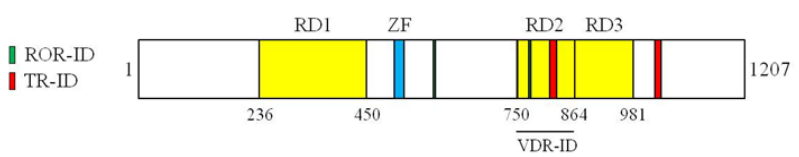

Fig. 2. Schematic of rat HR functional domains. Repression domains (yellow: RD1, 236-450; RD2, 750-864; RD3, 864981); ROR-interacting domains (green: ROR-ID1, 586-590; ROR-ID2, 778-782); TR-interacting domains (red: TR-ID1, 816-830; TR-ID2, 1026-1038); VDR-interacting domains (overlaps with RD3, 750-864). ZF indicates zinc-finger domain (621-646) (Thompson, 2009).

al., 2001; Potter et al., 2002; Thompson et al., 1997).

Deletion mapping of $H R$ revealed three repression domains (RD) that span amino acids 236-450 (RD1), 568864 (RD2), and 864-981 (RD3) (Fig. 2). The repression activity usually occurs through interaction with histone deacetylases (HDACs) (Burke et al., 2000; Glass et al., 2000; Pazin et al., 1997). The HR protein interacts with several HDACs, including HDACs 1,3 , and 5 , and the repression activity of $\mathrm{HR}$ is reduced on treatment with HDAC inhibitors. Furthermore, HR localizes in the nuclear matrix-associated deacetylase body, which comprises corepressors and HDAC complexes (Potter et al., 2001; Potter et al., 2002, Downes et al., 2000). This evidence suggests that HR may contribute to brain or CNS development through TR, acting as a transcriptional corepressor.

The HR protein interacts with another nuclear receptor, $\operatorname{ROR} \alpha$, which plays an important role in cerebellar development, lipid metabolism, and neoplasia (Gigue're., 1999; Moraitis et al., 2003). HR binds to ROR $\alpha$ using two interaction motifs, containing an LXXLL consensus sequence, and represses transcriptional activation by $\operatorname{ROR} \alpha$ (Moraitis et al., 2002). Cotransfection analysis revealed that $\mathrm{HR}$ represses transcriptional activation by all ROR isoforms- $\alpha, \beta$, and $\gamma$. Interestingly, the repression activity of $\operatorname{ROR} \alpha$ by HR is dependent on two LXXLL motifs, as mutations in these motifs abolished repression activity by $\mathrm{HR}$, while these mutations did not affect the repression activity of TR by HR (Moraitis et al., 2002).

\section{Interaction with the vitamin $D$ receptor}

Although HR interacts with $\operatorname{TR}$ and $\operatorname{ROR} \alpha$, this is not enough to explain the skin phenotype in HR mutants, because there is no evidence that defects in these receptors cause a phenotype that is as striking as the complete hair loss that is observed in HR mutants (Alonso et al, 2003). On the other hand, mutants with a deletion in the VDR manifest a hair loss phenotype, 
which resembles that of $H R$ mutant in mice and humans (Li et al., 1997; Yoshizawa et al., 1997).

The VDR not only mediates signals of 1, 25-dihydroxyvitamin D3 $\left(1,25(\mathrm{OH})_{2} \mathrm{D}_{3}\right)$ but also acts as a transcription factor, even in the absence of vitamin $\mathrm{D}$. Targeted gene deletion studies revealed that VDR is associated with multiple biological processes, especially the progression of the normal hair cycle in mammalian skin (Yoshizawa et al., 1997; Li et al., 1997; Malloy et al., 1999; Hirst et al., 1985; Hughes et al., 1988; Rut et al., 1994).

VDR regulates gene expression by forming a heterodimer with RXR and binding to a vitamin D-responsive element in target genes. As a partner of the heterodimer of VDR, $\operatorname{RXR} \alpha$ is relevant for hair cycling, since conditional inactivation of $\operatorname{RXR} \alpha$ in mice caused alopecia, as in VDR-null mice (Li et al., 2000). GST pull-down assays revealed that $H R$ interacts with VDR protein in vitro, and this interaction is unaffected by the $1,25(\mathrm{OH})_{2} \mathrm{D}_{3}$ ligand. Coimmunoprecipitation experiments also showed an interaction between HR and VDR in mammalian cells (Hsieh et al., 2003). The interaction domain of HR for VDR overlaps with the interaction domains for TR and ROR $\alpha$ (Fig. 2), and the minimal amino acid region was mapped to 750-864 (RD2) of HR (Hsieh et al., 2003). The transcriptional repression of VDR by HR occurs both in the presence and absence of its ligand, vitamin $D$, which is different from that of TR, in that HR mediates repression only by unliganded TR (Potter et al., 2001; Hsieh et al., 2003). In humans, HR interacts with VDR and represses the reporter activity of its target genes, such as involucrin, transglutaminase, PLC- $\gamma 1$, and 24-hydroxylase, in human keratinocytes (Zhongjjan et al., 2006). In situ hybridization assay revealed that $H R$ and VDR mRNA colocalize in a subset of cells in murine HFs, including the matrix and ORS (Hsieh et al., 2003). Immunostaining showed that both nuclear proteins are colocalized in a subset of HF cells in human skin (Zhongjjan et al., 2006). These results support the biochemically defined evidence of an interaction between $H R$ and VDR in vivo in mouse and human skin.

\section{Regulation of Hair Cycle and Hair Folli- cle Structure}

\section{Mutant mice of hairless gene}

Mouse models of various $\mathrm{Hr}$ mutations, such as $\mathrm{Hr}^{\mathrm{hr}}$, $\mathrm{Hr}^{\text {rh }}$, and $\mathrm{Hr}^{\text {m1Enu}}$, have been actively studied to understand the pathophysiology of human hair loss disorders (Cachon et al., 1994; Ahmad et al., 1998c; Panteleyev et al., 1998; Nam et al., 2006). Homozygous mutant mice with autosomal recessive mutations in $\mathrm{Hr}$ display a distinct phenotype with strikingly similar patterns of hair loss. These mutant mice grow hair normally in the postnatal stages; however, they shed hair progressively from the eyelids to the hind limbs and subsequently develop alopecia by the third week of postnatal life. Additionally, targeted disruption of $\mathrm{Hr}$ also causes a hair loss phenotype, which is restored by the expression of $\mathrm{HR}$ in keratinocytes (Beaudoin et al., 2005; Thompson et al., 2006). In $\mathrm{Hr}^{\text {hr }}$ mice, apoptotic cell death in HFs is observed in the transition stages from the catagen to anagen, suggesting that $H R$ may play a role in regulating the HF growth cycle (Panteleyev et al., 1999).

Mutant mice with a loss of function in $\mathrm{Hr}$ display the hair loss phenotype, which suggests that null or a lack of functional HR causes the hair loss phenotype. Recently, it was shown that dysregulation of HR expression also causes the hair loss phenotype. The 'hairpoor' $\left(\mathrm{Hr}^{\mathrm{H}}\right)$ and Naked $\left(\mathrm{Hr}^{\mathrm{M}}\right)$ mice display a different hair loss phenotype from those reported in mice with a lossof-function mutation in HR (Baek et al., 2009). The $\mathrm{Hr}^{\mathrm{HP}} /+$ mouse has short and sparse hair at early ages but gradually lose hair and become almost bald at age 40 weeks, while homozygote $\left(\mathrm{Hr}^{\mathrm{HP}} / \mathrm{Hr}^{\mathrm{HP}}\right)$ mice are born Hairless and stay naked (Baek et al., 2009). We found that this $\mathrm{Hr}^{\mathrm{HP}}$ mouse harbors a mutation in the $5^{\prime}$ untranslated region (UTR) of the $\mathrm{Hr}$ gene, and it causes overexpression of HR protein (Baek et al., 2009; Kim et al., 2010). This evidence has revealed that both lossand gain-of-function mutations in $\mathrm{Hr}$ cause the hair loss phenotype, which suggests that expressional regulation of $\mathrm{Hr}$ is critical for maintenance of the hair cycle or development of HF.

\section{Regulation of hair follicle structure}

Keratins are critical components of the HF. The hair shaft is highly keratinized tissue, and its major components are hair keratins (Langbein et al., 2005). The keratins are divided into two types-type I and type II-and their heterodimerization forms intermediate filaments that provide resilience to hair. Keratin is produced by keratinocytes, which multiply and differentiate. While some keratinocytes become epithelial cells of the ORS and IRS, some become elongated to form the hair shaft (Coulombe et al., 2002; Moll et al., 2008). Epithelial keratins are widely expressed in the ORS and IRS of the HF (Langbein et al., 2003; Langbein et al., 2001).

Keratin expression is regulated by several signaling pathways and transcription factors, such as Lef1 (a key transcription factor in Wnt signaling), Msx2, Foxn1, and Hoxc13 (DasGupta et al., 1999; Merrill et al., 2001; Ma et al., 2003; Schlake et al., 2000; Tkatchenko et al., 2001). Recently, we found that HR regulates the ex- 
pression of keratins that reside in the IRS. The IRS forms its structure by obligate heterodimerization of specified keratins. Type I IRS keratin genes (ie, Krt25, Krt27, and Krt28) and the type II IRS keratin gene Krt71 have been identified as specifically expressed in the IRS and are known to support the structures of the IRS cuticle, Huxley's layer, and Henle's layer (Runkel et al., 2006; Tanaka et al., 2007). We observed that the expression of Krt25, Krt27, Krt28, Krt71, and Tchh is consistently affected by HR, both in vivo and in vitro (in submission). These results suggest that $H R$ affects the formation of the HF through regulation of keratin expression in the IRS.

\section{Association with the Wnt Signaling Path- way}

Wnt/ $\beta$-catenin signaling plays a crucial role not only in $\mathrm{HF}$ morphogenesis but also in the regeneration of the $\mathrm{HF}$ through regulation of anagen initiation in the adult hair cycle (Ahmad et al., 1998c; Huelsken et al., 2001; Beaudoin et al., 2005; Stenn et al., 2001). The $\beta$-catenin protein, a key molecule of the Wnt signaling pathway, is activated and translocated into the nucleus when a Wnt protein binds to its receptor, Frizzled. In the nucleus, $\beta$-catenin forms a complex with Lef1/Tcf transcription factors and regulates target gene expression (Huelsken et al., 2001). Inactivation of Wnt signaling occurs through its inhibitors, and keratinocyte cells, including the Dickkopf (Dkk) family, Sclerostin domain-containing protein 1 (Sostdc1), Wnt inhibitory factor 1 (Wif), and the Secreted frizzled-related protein (Sfrp) family (Kawano et al., 2003).

\section{Transcriptional regulation of Wnt signaling in- hibitors}

The fact that induction of HR protein using transgenic systems rescues the Hairless phenotype of HR-null mice reveals that $H R$ functions in progenitor keratinocytes and induces the hair cycle, thus allowing HF regeneration (Beaudoin et al., 2005). This suggests that HR may regulate the Wnt signaling pathway, since this signaling directly regulates HF regeneration (Zarach et al., 2004; Beaudoin et al., 2005; Lo Celso et al., 2004). Gene expression profiling of $\mathrm{Hr}$ knockout and $\mathrm{Hr}$-rescued transgenic mice have revealed that the Wnt-responsive gene Axin2 is regulated by HR, which suggests that HR can promote the Wnt signaling pathway. In addition, the HR overexpression mouse $\mathrm{Hr}^{H P}$ shows increased expression of Myc and Ccnd1, target genes of Wnt signaling (Kim et al., 2010). As expected, the Wnt inhibitors Wise and Soggy are upregulated in $\mathrm{Hr}$ knockout mice and down- regulated in HR-rescued transgenic skin, showing an inverse relationship with $\mathrm{HR}$ expression in vivo (Beaudoin et al., 2005; Thompson et al., 2006). Furthermore, Sfrp2 mRNA expression is downregulated in $\mathrm{Hr}^{\mathrm{HD}}$ mouse skin (Kim et al., 2010). A promoter analysis has suggested that the regulation of Wnt inhibitor expression is regulated by HR specifically, because there is no such regulation that is detected by another corepressor, SMRT (Beaudoin et al., 2005; Thompson et al., 2006). These findings suggest that HR can modulate more than one regulator in the Wnt signaling pathway, and it appears to be crucial that the timing and level of HR protein expression are tightly regulated for normal HF development. Regulation of Wnt signaling by HR is one component of the complex interactions of signaling pathways in HF cycling. HR may regulate the expression of genes that modulate other signaling pathways, such as Shh, $\mathrm{BMP}$, and TGF- $\beta$, which regulate HF morphogenesis and cycling.

\section{Genetic Hair Disorders with HR Muta- tion}

\section{Atrichia with papular lesions and Alopecia uni- versalis congenita}

Atrichia with popular lesions (APL; MIM 209500) is a rare autosomal recessive disorder. Patients are born with natal hair, which falls out in the first few months of life and never replenishes. In addition to the complete absence of any hair, including scalp hair, eyebrows, eyelashes, and pubic hair, they also develop papular eruptions on the scalp, cheeks, elbows, arms, knees, and thighs. Histological examination of a patient's skin has revealed the absence of HFs (Ahmad et al., 1998a; Henn et al., 2002; Sprecher et al., 1999).

A similar hair disorder as APL, alopecia universalis congenita (ALUNC; MIM 203655) also manifests as a lack of body hair without papular lesions and has been found to be caused by mutations in the $H R$ gene. A skin biopsy of one patient revealed that there were few HFs present, without hair in them (Ahmad et al., 1998b). Multiple kinds of mutations of the human $H R$ gene with a loss of function have been reported (Table 1).

As a model for APL, we and others have reported hairless mutant mice that have a similar phenotype as APL. Histological analyses have revealed that they show an absence of HFs and the formation of abnormal structures, such as utricles and dermal cysts, in the skin (Ahmad et al., 1998c; Panteleyev et al., 1998; Nam et al., 2006; Zarach et al., 2004; Sundberg, 1994). APL is also caused by recessive mutations in the VDR gene, as found in a vitamin D-dependent rickets type $2 \mathrm{~A}$ 
Table 1. HR mutations responsible for genetic human hair disorders

\begin{tabular}{|c|c|c|}
\hline Disease & Mutation & References \\
\hline \multirow[t]{18}{*}{ APL } & 3434delC* & Sprecher et al., 1999 \\
\hline & N970S & Kruse et al., 1999 \\
\hline & V1056M & Zlotogorski et al., 2002 \\
\hline & Q1176X & Henn et al., 2002 \\
\hline & R33X & Zlotogorski et al., 2002 \\
\hline & Q478X & Indelman et al., 2003 \\
\hline & E583V & Paradisi et al., 2003 \\
\hline & C622G & \\
\hline & R154X & Ashoor et al., 2005 \\
\hline & Q515X & \\
\hline & $431 \mathrm{delC}^{*}$ & John et al., 2005 \\
\hline & 2021 delG* & \\
\hline & G202InsCTTCCCCCAGG* & Wali et al., 2006 \\
\hline & Q260X & Michailidis et al., 2007 \\
\hline & W699X & \\
\hline & Q323X & Kim et al., 2007 \\
\hline & Q502X & \\
\hline & 1839-1841delATG* & Balighi et al., 2009 \\
\hline \multirow[t]{4}{*}{ ALUNC } & T1022A & Ahmad et al., 1998a \\
\hline & V1136D & Cichon et al., 1998 \\
\hline & D1012N & Klein et al., 2002 \\
\hline & 2661dupG* & Betz et al., 2007 \\
\hline \multirow[t]{14}{*}{ MUHH } & $A-321 G^{*}$ & Wen et al., 2009 \\
\hline & $\mathrm{A}-321 \mathrm{~T}^{\star}$ & \\
\hline & $\mathrm{T}-320 \mathrm{~A}^{*}$ & \\
\hline & G-319A* & \\
\hline & $\mathrm{C}-315 \mathrm{~T}^{\star}$ & \\
\hline & $C-302 A^{*}$ & \\
\hline & $\mathrm{T}-251 \mathrm{~A}^{*}$ & \\
\hline & $\mathrm{C}-248 \mathrm{G}^{*}$ & \\
\hline & G-245A* & \\
\hline & G-239C* & \\
\hline & $\mathrm{T}-218 \mathrm{C}^{\star}$ & \\
\hline & $\mathrm{A}-217 \mathrm{G}^{*}$ & \\
\hline & $\mathrm{T}-320 \mathrm{C}^{*}$ & Kim et al., 2010 \\
\hline & & Wen et al., 2009 \\
\hline
\end{tabular}

*indicates nucleotide sequences.

(VDDR2A; OMIM 277440) patient (Miller et al., 2001). This suggests that there is a functional relationship between HR and VDR in controlling postnatal cycling of the HF, as mentioned above.

\section{Marie Unna hereditary hypotrichosis}

Autosomal dominant Marie Unna hereditary hypotrichosis (MUHH; MIM 146550) is characterized by abnormal hair density in the scalp, eyebrows, eyelashes, and body. Affected individuals are born with sparse hair that is characteristically coarse, wiry, and twisted in early childhood and progress to complete baldness (Argenzia- no et al., 1999; Unna., 1925; Ludwig., 1953). Although genetic heterogeneity has been reported in Dutch, Belgian, British, French, German, and Chinese families, the majority of $\mathrm{MUHH}$ pedigrees has been linked to chromosome 8p21, near the $H R$ gene (Sreekumar et al., 2000; van Steensel et al., 1999; Lefevre et al., 2000; Cichon et al., 2000; Yan et al., 2004; He et al., 2004). In addition to the characteristic sparse hair phenotype at birth, $\mathrm{MUHH}$ is different from other $H R$ defect-associated disorders, in that it is inherited in a dominant manner, whereas the other disorders are inherited in a recessive mode. Recently, 13 distinct mutations were identified in patients with $\mathrm{MUHH}$. Interestingly, all of these mutations were present in the $5^{\prime}$ UTR of $H R$ (Wen et al., 2009), in contrast to mutations present in the coding sequences of $H R$ that result in a loss of function. We and others have shown that all of these mutations upregulate $\mathrm{HR}$ expression at the translational level using a reporter system (Wen et al., 2009; Kim et al., 2010). In fact, in an animal model, the $\mathrm{Hr}^{H P}$ mouse, which has a mutation located at the same position of the $H R$ gene as in $\mathrm{MUHH}$, the expression of $\mathrm{HR}$ was found to be greatly increased compared with that of wild-type mice (Kim et al., 2010).

\section{Conclusion}

The study of HR has suggested that HR functions in HF development and cycling. As a transcription factor, HR regulates the expression of many genes that are components of the HF or key molecules of the signaling pathway for hair cycling and HF maintenance. There may be many more genes that remain to be discovered as targets of $H R$ in the skin. Identification of them will greatly facilitate the elucidation of the biological functions of HR in developmental processes and the molecular mechanisms of HF cycling. The HF is a very dynamic organ, with continuous regeneration throughout an organism's life, and the presence and behaviors of its stem cells are only recently slowly being uncovered. Since HR associates with Wnt signaling, which is an essential pathway for stem cell function, and is expressed in ORS cells, which are the same lineage as bulge cells, the elucidation of HR function in HF stem cells will be required. Further study of HR function in HF cycling as well as in stem cell biology will provide a better understanding of HF development and may help us understand the development of other HR-expressing tissues, such as brain.

\section{Acknowledgements}

This work was supported by the Basic Science 
Research Program of the National Research Foundation of Korea (NRF) and funded by the Ministry of Education, Science and Technology (2009-0066830).

\section{References}

Ahmad, W., Faiyaz ul Haque, M., Brancolini, V., Tsou, H.C., ul Haque, S., Lam, H., Aita, V.M., Owen, J., deBlaquiere, M., Frank, J., Cserhalmi-Friedman, P.B., Leask, A., McGrath, J.A., Peacocke, M., Ahmad, M., Ott, J., and Christiano, A.M. (1998a). Alopecia universalis associated with a mutation in the human Hairless gene. Science 279, 720-724.

Ahmad, W., Irvine, A.D., Lam, H., Buckley, C., Bingham, E.A., Panteleyev, A.A., Ahmad, M., McGrath, J.A., and Christiano, A.M. (1998b). A missense mutation in the zinc-finger domain of the human Hairless gene underlies congenital atrichia in a family of Irish travellers. $A m$. J. Hum. Genet. 63, 984-991.

Ahmad, W., Panteleyev, A.A., Sundberg, J.P., and Christiano, A.M. (1998c). Molecular basis for the rhino (hrrh-8J) phenotype: a nonsense mutation in the mouse Hairless gene. Genomics 53, 383-386.

Aita, V.M., Ahmad, W., Panteleyev, A.A., Kozlowska, U., Kozlowska, A., Gilliam, T.C., Jablonska, S., and Christiano, A.M. (2000). A novel missense mutation $(\mathrm{C} 622 \mathrm{G})$ in the zinc-finger domain of the human Hairless gene associated with congenital atrichia with papular lesions. Exp. Dermatol. 9, 157-162.

Alonso, L.C., and Rosenfield, R.L. (2003). Molecular genetic and endocrine mechanisms of hair growth. Horm. Res. $60,1-13$

Argenziano, G., Sammarco, E., Rossi, A., Delfino, M., and Calvieri, S. (1999). Marie Unna hereditary hypotrichosis. Eur. J. Dermatol. 9, 278-280.

Ashoor, G.G., Greenstein, R.M., Lam, H., Martinez-Mir, A., Zlotogorski, A., and Christiano, A.M. (2005). Novel compound heterozygous nonsense mutations in the Hairless gene causing atrichia with papular lesions. J. Dermatol. Sci. 40, 29-33.

Baek, I.C., Kim, J.K., Cho, K.H., Cha, D.S., Cho, J.W., Park, J.K., Song, C.W., and Yoon, S.K. (2009). A novel mutation in $\mathrm{Hr}$ causes abnormal hair follicle morphogenesis in hairpoor mouse, an animal model for Marie Unna Hereditary Hypotrichosis. Mamm. Genome. 20, 350358.

Balighi, K., Lajevardi, V., Moeineddin, F., Jelani, M., Tamizifar, B., Nikoo, A., Javed, Q., Ahmad, W., and Parvaneh, $N$. (2009). A novel deletion mutation in the human Hairless (HR) gene in an Iranian family with atrichia and papular lesions. Clin. Exp. Dermatol, 34, e498-500.

Beaudoin, G.M., 3rd, Sisk, J.M., Coulombe, P.A., and Thompson, C.C. (2005). Hairless triggers reactivation of hair growth by promoting Wnt signaling. Proc. Natl. Acad. Sci. U.S.A. 102, 14653-14658.

Betz, R.C., Indelman, M., Pforr, J., Schreiner, F., Bauer, R., Bergman, R., Lentze, M.J., Nothen, M.M., Cichon, S., and Sprecher, E. (2007). Identification of mutations in the human Hairless gene in two new families with congenital atrichia. Arch. Dermatol. Res. 299, 157-161.

Blanpain, C., and Fuchs, E. (2006). Epidermal stem cells of the skin. Annu. Rev. Cell. Dev. Biol. 22, 339-373.

Burke, L.J., and Baniahmad, A. (2000). Co-repressors 2000. FASEB J. 14, 1876-1888.

Cachon-Gonzalez, M.B., Fenner, S., Coffin, J.M., Moran, C., Best, S., and Stoye, J.P. (1994). Structure and expression of the Hairless gene of mice. Proc. Natl. Acad. Sci. U.S.A. 91, 7717-7721.

Cachon-Gonzalez, M.B., San-Jose, I., Cano, A., Vega, J.A., Garcia, N., Freeman, T., Schimmang, T., and Stoye, J.P. (1999). The Hairless gene of the mouse: relationship of phenotypic effects with expression profile and genotype. Dev. Dyn. 216, 113-126.

Chen, J.D., and Evans, R.M. (1995). A transcriptional co-repressor that interacts with nuclear hormone receptors. Nature 377, 454-457.

Cichon, S., Anker, M., Vogt, I.R., Rohleder, H., Putzstuck, M., Hillmer, A., Farooq, S.A., Al-Dhafri, K.S., Ahmad, M., Haque, S., Rietschel, M., Propping, P., Kruse, R., and Nothen, M.M. (1998). Cloning, genomic organization, alternative transcripts and mutational analysis of the gene responsible for autosomal recessive universal congenital alopecia. Hum. Mol. Genet. 7, 1671-1679.

Cichon, S., Kruse, R., Hillmer, A.M., Kukuk, G., Anker, M., Altland, K., Knapp, M., Propping, P., and Nothen, M.M. (2000). A distinct gene close to the Hairless locus on chromosome $8 p$ underlies hereditary Marie Unna type hypotrichosis in a German family. Br. J. Dermatol. 143, 811-814.

Coulombe, P.A., and Omary, M.B. (2002). 'Hard' and 'soft' principles defining the structure, function and regulation of keratin intermediate filaments. Curr. Opin. Cell Biol. 14, 110-122.

DasGupta, R., and Fuchs, E. (1999). Multiple roles for activated LEF/TCF transcription complexes during hair follicle development and differentiation. Development 126, 45574568.

Djabali, K., Aita, V.M., and Christiano, A.M. (2001). Hairless is translocated to the nucleus via a novel bipartite nuclear localization signal and is associated with the nuclear matrix. J. Cell. Sci. 114, 367-376.

Downes, M., Ordentlich, P., Kao, H.Y., Alvarez, J.G., and Evans, R.M. (2000). Identification of a nuclear domain with deacetylase activity. Proc. Natl. Acad. Sci. U.S.A. 97, 10330-10335.

Giguere, V. (1999). Orphan nuclear receptors: from gene to function. Endocr. Rev. 20, 689-725.

Glass, C.K., and Rosenfeld, M.G. (2000). The coregulator exchange in transcriptional functions of nuclear receptors. Genes Dev. 14, 121-141.

He, P.P., Zhang, X.J., Yang, Q., Li, M., Liang, Y.H., Yang, S., Yan, K.L., Cui, Y., Shen, Y.Y., Wang, H.Y., Sun, L.D., Du, W.H., Shen, Y.J., Xu, S.J., and Huang, W. (2004). Refinement of a locus for Marie Unna hereditary hypotrichosis to a 1.1-cM interval at 8p21.3. Br. J. Dermatol. $150,837-842$.

Henn, W., Zlotogorski, A., Lam, H., Martinez-Mir, A., Zaun, 
H., and Christiano, A.M. (2002). Atrichia with papular lesions resulting from compound heterozygous mutations in the Hairless gene: A lesson for differential diagnosis of alopecia universalis. J. Am. Acad. Dermatol. 47, 519-523.

Hirst, M.A., Hochman, H.I., and Feldman, D. (1985). Vitamin $D$ resistance and alopecia: a kindred with normal 1,25-dihydroxyvitamin $\mathrm{D}$ binding, but decreased receptor affinity for deoxyribonucleic acid. J. Clin. Endocrinol. Metab. 60, 490-495.

Horlein, A.J., Naar, A.M., Heinzel, T., Torchia, J., Gloss, B., Kurokawa, R., Ryan, A., Kamei, Y., Soderstrom, M., Glass, C.K., and Rosenfeld, M.G. (1995). Ligand-independent repression by the thyroid hormone receptor mediated by a nuclear receptor co-repressor. Nature 377, 397-404.

Hsieh, J.C., Sisk, J.M., Jurutka, P.W., Haussler, C.A., Slater, S.A., Haussler, M.R., and Thompson, C.C. (2003). Physical and functional interaction between the vitamin $D$ receptor and Hairless corepressor, two proteins required for hair cycling. J. Biol. Chem. 278, 38665-38674.

Huelsken, J., and Birchmeier, W. (2001). New aspects of Wnt signaling pathways in higher vertebrates. Curr. Opin. Genet. Dev. 11, 547-553.

Huelsken, J., Vogel, R., Erdmann, B., Cotsarelis, G., and Birchmeier, W. (2001). beta-Catenin controls hair follicle morphogenesis and stem cell differentiation in the skin. Cell 105, 533-545.

Hughes, M.R., Malloy, P.J., Kieback, D.G., Kesterson, R.A., Pike, J.W., Feldman, D., and O'Malley, B.W. (1988). Point mutations in the human vitamin $D$ receptor gene associated with hypocalcemic rickets. Science 242, 17021705.

Indelman, M., Bergman, R., Lestringant, G.G., Peer, G., and Sprecher, E. (2003). Compound heterozygosity for mutations in the Hairless gene causes atrichia with papular lesions. Br. J. Dermatol. 148, 553-557.

Jepsen, K., and Rosenfeld, M.G. (2002). Biological roles and mechanistic actions of co-repressor complexes. J. Cell. Sci. 115, 689-698.

John, P., Aslam, M., Rafiq, M.A., Amin-ud-din, M., Haque, S., and Ahmad, W. (2005). Atrichia with papular lesions in two Pakistani consanguineous families resulting from mutations in the human Hairless gene. Arch. Dermatol. Res. 297, 226-230.

Kawano, Y., and Kypta, R. (2003). Secreted antagonists of the Wnt signalling pathway. J. Cell. Sci. 116, 2627-2634.

Kim, H., Wajid, M., Kraemer, L., Shimomura, Y., and Christiano, A.M. (2007). Nonsense mutations in the Hairless gene underlie APL in five families of Pakistani origin. J. Dermatol. Sci. 48, 207-211.

Kim, J.K., Kim, E., Baek, I.C., Kim, B.K., Cho, A.R., Kim, T.Y., Song, C.W., Seong, J.K., Yoon, J.B., Stenn, K.S., Parimoo, S., and Yoon, S.K. (2010). Overexpression of $\mathrm{Hr}$ links excessive induction of Wnt signaling to Marie Unna hereditary hypotrichosis. Hum. Mol. Genet. 19, 445-453.

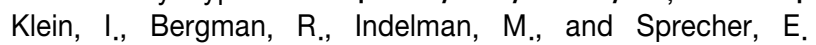
(2002). A novel missense mutation affecting the human Hairless thyroid receptor interacting domain 2 causes congenital atrichia. J. Invest. Dermatol. 119, 920-922.

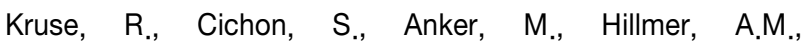
Barros-Nunez, P., Cantu, J.M., Leal, E., Weinlich, G.,

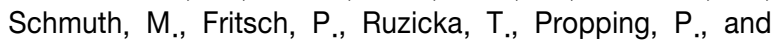
Nothen, M.M. (1999). Novel Hairless mutations in two kindreds with autosomal recessive papular atrichia. $J$. Invest. Dermatol. 113, 954-959.

Langbein, L., Rogers, M.A., Praetzel, S., Winter, H., and Schweizer, J. (2003). K6irs1, K6irs2, K6irs3, and K6irs4 represent the inner-root-sheath-specific type II epithelial keratins of the human hair follicle. J. Invest. Dermatol. $120,512-522$.

Langbein, L., Rogers, M.A., Winter, H., Praetzel, S., and Schweizer, J. (2001). The catalog of human hair keratins. II. Expression of the six type II members in the hair follicle and the combined catalog of human type I and II keratins. J. Biol. Chem. 276, 35123-35132.

Langbein, L., and Schweizer, J. (2005). Keratins of the human hair follicle. Int. Rev. Cytol. 243, 1-78.

Lefevre, $P_{\text {., Rochat, }}$., Bodemer, C., Vabres, $P_{\text {., }}$

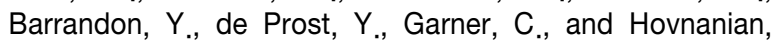
A. (2000). Linkage of Marie-Unna hypotrichosis locus to chromosome 8p21 and exclusion of 10 genes including the Hairless gene by mutation analysis. Eur. J. Hum. Genet. 8, 273-279.

Li, M., Indra, A.K., Warot, X., Brocard, J., Messaddeq, N., Kato, S., Metzger, D., and Chambon, P. (2000). Skin abnormalities generated by temporally controlled RXRalpha mutations in mouse epidermis. Nature 407, 633-636.

Li, Y.C., Pirro, A.E., Amling, M., Delling, G., Baron, R., Bronson, R., and Demay, M.B. (1997). Targeted ablation of the vitamin D receptor: an animal model of vitamin D-dependent rickets type II with alopecia. Proc. Natl. Acad. Sci. U.S.A. 94, 9831-9835.

Lo Celso, C., Prowse, D.M., and Watt, F.M. (2004). Transient activation of beta-catenin signalling in adult mouse epidermis is sufficient to induce new hair follicles but continuous activation is required to maintain hair follicle tumours. Development 131, 1787-1799.

Ludwig, E. (1953). Hypotrichosis congenital hereditaria type M. Unna. Arch. Dermatol. Syph. 196, 261-278.

Ma, L., Liu, J., Wu, T., Plikus, M., Jiang, T.X., Bi, Q., Liu,

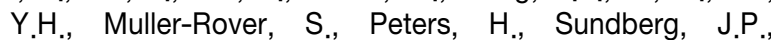
Maxson, R., Maas, R.L., and Chuong, C.M. (2003). 'Cyclic alopecia' in Msx2 mutants: defects in hair cycling and hair shaft differentiation. Development 130, 379-389.

Malloy, P.J., Pike, J.W., and Feldman, D. (1999). The vitamin $D$ receptor and the syndrome of hereditary 1,25-dihydroxyvitamin D-resistant rickets. Endocr. Rev. 20, 156-188.

Mangelsdorf, D.J., and Evans, R.M. (1995). The RXR heterodimers and orphan receptors. Cell 83, 841-850.

Merrill, B.J., Gat, U., DasGupta, R., and Fuchs, E. (2001). Tcf3 and Lef1 regulate lineage differentiation of multipotent stem cells in skin. Genes Dev. 15, 1688-1705.

Michailidis, E., Theos, A., Zlotogorski, A., Martinez-Mir, A., and Christiano, A.M. (2007). Atrichia with papular lesions resulting from novel compound heterozygous mutations in the human Hairless gene. Pediatr. Dermatol. 24, E79-82. 
Millar, S.E. (2002). Molecular mechanisms regulating hair follicle development. J. Invest. Dermatol. 118, 216-225.

Miller, J., Djabali, K., Chen, T., Liu, Y., loffreda, M., Lyle, S., Christiano, A.M., Holick, M., and Cotsarelis, G. (2001). Atrichia caused by mutations in the vitamin $D$ receptor gene is a phenocopy of generalized atrichia caused by mutations in the Hairless gene. J. Invest. Dermatol. 117, 612-617.

Moll, R., Divo, M., and Langbein, L. (2008). The human keratins: biology and pathology. Histochem. Cell Biol. 129, 705-733.

Moraitis, A.N., and Giguere, V. (2003). The co-repressor Hairless protects RORalpha orphan nuclear receptor from proteasome-mediated degradation. J. Biol. Chem. 278, 52511-52518.

Moraitis, A.N., Giguere, V., and Thompson, C.C. (2002). Novel mechanism of nuclear receptor corepressor interaction dictated by activation function 2 helix determinants. Mol. Cell, Biol, 22, 6831-6841.

Nam, Y., Kim, J.K., Cha, D.S., Cho, J.W., Cho, K.H., Yoon, S., Yoon, J.B., Oh, Y.S., Suh, J.G., Han, S.S., Song, C.W., and Yoon, S.K. (2006). A novel missense mutation in the mouse Hairless gene causes irreversible hair loss: genetic and molecular analyses of $\mathrm{Hr}$ m1Enu. Genomics 87, 520-526.

Panteleyev, A.A., Ahmad, W., Malashenko, A.M., Ignatieva, E.L., Paus, R., Sundberg, J.P., and Christiano, A.M. (1998). Molecular basis for the rhino Yurlovo (hr(rhY)) phenotype: severe skin abnormalities and female reproductive defects associated with an insertion in the Hairless gene. Exp. Dermatol. 7, 281-288.

Panteleyev, A.A., Botchkareva, N.V., Sundberg, J.P., Christiano, A.M., and Paus, R. (1999). The role of the Hairless (hr) gene in the regulation of hair follicle catagen transformation. Am. J. Pathol. 155, 159-171.

Paradisi, M., Chuang, G.S., Angelo, C., Pedicelli, C., Martinez-Mir, A., and Christiano, A.M. (2003). Atrichia with papular lesions resulting from a novel homozygous missense mutation in the Hairless gene. Clin. Exp. Dermatol. 28, 535-538.

Paus, R., and Foitzik, K. (2004). In search of the "hair cycle clock": a guided tour. Differentiation 72, 489-511.

Pazin, M.J., and Kadonaga, J.T. (1997). What's up and down with histone deacetylation and transcription? Cell 89, 325-328.

Potter, G.B., Beaudoin, G.M., 3rd, DeRenzo, C.L., Zarach, J.M., Chen, S.H., and Thompson, C.C. (2001). The Hairless gene mutated in congenital hair loss disorders encodes a novel nuclear receptor corepressor. Genes Dev. 15, 2687-2701.

Potter, G.B., Zarach, J.M., Sisk, J.M., and Thompson, C.C. (2002). The thyroid hormone-regulated corepressor Hairless associates with histone deacetylases in neonatal rat brain. Mol. Endocrinol. 16, 2547-2560.

Privalsky, M.L. (2004). The role of corepressors in transcriptional regulation by nuclear hormone receptors. Annu. Rev. Physiol. 66, 315-360.

Runkel, F., Klaften, M., Koch, K., Bohnert, V., Bussow, H.,

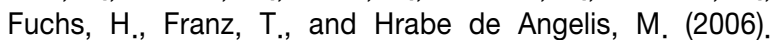

Morphologic and molecular characterization of two novel Krt71 (Krt2-6g) mutations: Krt71rco12 and Krt71rco13. Mamm. Genome 17, 1172-1182.

Rut, A.R., Hewison, M., Kristjansson, K., Luisi, B., Hughes, M.R., and O'Riordan, J.L. (1994). Two mutations causing vitamin $D$ resistant rickets: modelling on the basis of steroid hormone receptor DNA-binding domain crystal structures. Clin. Endocrinol. (Oxf). 41, 581-590.

Sande, S., and Privalsky, M.L. (1996). Identification of TRACs (T3 receptor-associating cofactors), a family of cofactors that associate with, and modulate the activity of, nuclear hormone receptors. Mol. Endocrinol. 10, 813825.

Schlake, T., Schorpp, M., Maul-Pavicic, A., Malashenko, A.M., and Boehm, T. (2000). Forkhead/winged-helix transcription factor Whn regulates hair keratin gene expression: molecular analysis of the nude skin phenotype. Dev. Dyn. 217, 368-376.

Shimomura, Y., and Christiano, A.M. (2010). Biology and genetics of hair. Annu. Rev. Genomics Hum. Genet. 11, 109-132.

Smith, C.L., and O'Malley, B.W. (2004). Coregulator function: a key to understanding tissue specificity of selective receptor modulators. Endocr. Rev. 25, 45-71.

Sprecher, E., Bergman, R., Szargel, R., Friedman-Birnbaum, R., and Cohen, N. (1999). Identification of a genetic defect in the Hairless gene in atrichia with papular lesions: evidence for phenotypic heterogeneity among inherited atrichias. Am. J. Hum. Genet. 64, 1323-1329.

Sreekumar, G.P., Roberts, J.L., Wong, C.Q., Stenn, K.S., and Parimoo, S. (2000). Marie Unna hereditary hypotrichosis gene maps to human chromosome 8p21 near Hairless. J. Invest. Dermatol. 114, 595-597.

Stenn, K.S., and Paus, R. (2001). Controls of hair follicle cycling. Physiol. Rev. 81, 449-494.

Stoye, J.P., Fenner, S., Greenoak, G.E., Moran, C., and Coffin, J.M. (1988). Role of endogenous retroviruses as mutagens: the Hairless mutation of mice. Cell 54, 383391.

Sundberg, J.P. (1994). Handbook of mouse mutations with skin and hair abnormalities: animal models and biomedical tools (Boca Raton: CRC Press).

Tanaka, S., Miura, I., Yoshiki, A., Kato, Y., Yokoyama, H., Shinogi, A., Masuya, H., Wakana, S., Tamura, M., and Shiroishi, T. (2007). Mutations in the helix termination motif of mouse type I IRS keratin genes impair the assembly of keratin intermediate filament. Genomics 90, 703-711.

Thompson, C.C. (1996). Thyroid hormone-responsive genes in developing cerebellum include a novel synaptotagmin and a Hairless homolog. J. Neurosci. 16, 7832-7840.

Thompson, C.C. (2009). Hairless is a nuclear receptor corepressor essential for skin function. Nucl. Recept. Signal. 7, 1-11.

Thompson, C.C., and Bottcher, M.C. (1997). The product of a thyroid hormone-responsive gene interacts with thyroid hormone receptors. Proc. Natl. Acad. Sci. U.S.A. 94, 8527-8532.

Thompson, C.C., Sisk, J.M., and Beaudoin, G.M., 3rd. 
(2006). Hairless and Wnt signaling: allies in epithelial stem cell differentiation. Cell Cycle 5, 1913-1917.

Tkatchenko, A.V., Visconti, R.P., Shang, L., Papenbrock, T., Pruett, N.D., Ito, T., Ogawa, M., and Awgulewitsch, A. (2001). Overexpression of Hoxc13 in differentiating keratinocytes results in downregulation of a novel hair keratin gene cluster and alopecia. Development 128, 1547-1558.

Unna, M. (1925). Ueber Hypotrichosis congenita hereditaria. Dermatol. Wochenschr. 81, 1167-1178.

van Steensel, M., Smith, F.J., Steijlen, P.M., Kluijt, I., Stevens, H.P., Messenger, A., Kremer, H., Dunnill, M.G., Kennedy, C., Munro, C.S., Doherty, V.R., McGrath, J.A., Covello, S.P., Coleman, C.M., Uitto, J., and McLean, W.H. (1999). The gene for hypotrichosis of Marie Unna maps between D8S258 and D8S298: exclusion of the $\mathrm{hr}$ gene by cDNA and genomic sequencing. Am. J. Hum. Genet. 65, 413-419.

Wali, A., Ansar, M., Khan, M.N., and Ahmad, W. (2006). Atrichia with papular lesions resulting from a novel insertion mutation in the human Hairless gene. Clin. Exp. Dermatol. 31, 695-698.

Wen, Y., Liu, Y., Xu, Y., Zhao, Y., Hua, R., Wang, K., Sun, M., Li, Y., Yang, S., Zhang, X.J., Kruse, R., Cichon, S., Betz, R.C., Nothen, M.M., van Steensel, M.A., van Geel, M., Steijlen, P.M., Hohl, D., Huber, M., Dunnill, G.S., Kennedy, C., Messenger, A., Munro, C.S., Terrinoni, A., Hovnanian, A., Bodemer, C., de Prost, Y., Paller, A.S., Irvine, A.D., Sinclair, R., Green, J., Shang, D., Liu, Q., Luo, Y., Jiang, L., Chen, H.D., Lo, W.H., McLean, W.H., He, C.D., and Zhang, X. (2009). Loss-of-function mutations of an inhibitory upstream ORF in the human
Hairless transcript cause Marie Unna hereditary hypotrichosis. Nat. Genet. 41, 228-233.

Xie, Z., Chang, S., Oda, Y., and Bikle, D.D. (2006). Hairless suppresses vitamin $D$ receptor transactivation in human keratinocytes. Endocrinology 147, 314-323.

Yan, K.L., He, P.P., Yang, S., Li, M., Yang, Q., Ren, Y.Q., Cui, Y., Gao, M., Xiao, F.L., Huang, W., and Zhang, X.J. (2004). Marie Unna hereditary hypotrichosis: report of a Chinese family and evidence for genetic heterogeneity. Clin. Exp. Dermatol, 29, 460-463.

Yoshizawa, T., Handa, Y., Uematsu, Y., Takeda, S., Sekine, K., Yoshihara, Y., Kawakami, T., Arioka, K., Sato, $\mathrm{H}_{\text {, }}$ Uchiyama, Y., Masushige, S., Fukamizu, A., Matsumoto, $T_{\text {., }}$ and Kato, S. (1997). Mice lacking the vitamin D receptor exhibit impaired bone formation, uterine hypoplasia and growth retardation after weaning. Nat. Genet. 16, 391-396.

Zarach, J.M., Beaudoin, G.M., 3rd, Coulombe, P.A., and Thompson, C.C. (2004). The co-repressor Hairless has a role in epithelial cell differentiation in the skin. Development 131, 4189-4200.

Zlotogorski, A., Martinez-Mir, A., Green, J., Lamdagger, $H_{\text {., }}$ Panteleyevdagger, A.A., Sinclair, R., and Christiano, A.M. (2002a). Evidence for pseudodominant inheritance of atrichia with papular lesions. J. Invest. Dermatol. 118, 881886.

Zlotogorski, A., Panteleyev, A.A., Aita, V.M., and Christiano, A.M. (2002b). Clinical and molecular diagnostic criteria of congenital atrichia with papular lesions. J. Invest. Dermatol. 118, 887-890. 